\title{
ESTIMATION THE NOISE IMMUNITY OF CONTINUOUS PHASE MODULATION SIGNALS WITH FULL RESPONSE BASED SIMULATION MODEL
}

DOI: |0.36724/2072-8735-202|-|5-|-52-56

\author{
Andrey I. Azarov, \\ Military Academy of the Strategic Missile Forces named \\ after Peter the Great, Balashikha, Russia, \\ azarofff1985@yandex.ru \\ Evgenyi V. Budarin, \\ West Department of Pushkov Institute of Terrestrial \\ Magnetism, lonosphere and Radio Wave Propagation, \\ Russian Academy of Sciences, Kaliningrad, Russia, \\ zhenyoker@yandex.ru
}

Manuscript received 14 September 2020;

Revised 28 October 2020;

Accepted 22 December 2020

Keywords: noise immunity, continuous phase modulation signals with full response, Euclidean distances, modulation index, bit error probability

\begin{abstract}
The problem of spectral load of communication channels is now becoming urgent, which determines the efforts of the world's leading tech communication companies to search for perspective signals. These signals must ensure compliance with international standards governing the use of frequency bands and the permissible level of out-of-band emissions and the required noise immunity of information transmission. The article deals with the noise immunity of continuous phase modulation signals research. A preliminary estimation is carried out by calculating the Euclidean distances between signals. The estimates of the noise immunity were obtained experimentally. The results of simulation are presented for fixed value of the signal to noise ratio for signals. Modulation indices and phase pulse were taken into account. The results of the study make it possible to emphasize the modulation indices for CPM FR signals, having more noise immunity then the known BPSK and MSK signals. Increasing the noise immunity becomes possible due to intersymbol phase communication. These signals are received according to the Viterbi algorithm. The results of the study show the values of the modulation indices to be of practical interest.
\end{abstract}

\section{Information about authors:}

Andrey I. Azarov, Cand. Sci. (Engineering) researcher Military Academy of the Strategic Missile Forces named after Peter the Great, Balashikha, Russia.

Evgenyi V. Budarin, engineer of the West Department of Pushkov Institute of Terrestrial Magnetism, lonosphere and Radio Wave Propagation, Russian Academy of Sciences, Kaliningrad, Russia

\section{Для цитирования:}

Азаров А.И., Бударин Е.В. Оценка помехоустойчивости частотно-модулированных сигналов с непрерывной фазой и полным откликом на основе имитационного моделирования // Т-Comm: Телекоммуникации и транспорт. 202I. Том I5. № I. С. 52-56.

For citation:

Azarov A.I., Budarin E.V. (202I) Estimation the noise immunity of continuous phase modulation signals with full response based simulation model. T-Comm, vol. I5, no.I, Pp. 52-56. (in Russian) 


\section{Introduction}

In modern digital communication systems (DCS) noise immunity is determined by the $B E P$ (bit error probability) value. In general the $B E P$ value depends on the bit energy to the noise power spectral density at the input of the receiver $E_{b} / N_{0}$, the parameters of communication channel, the modulation method, the number of levels use in a particular modulation method, the signal reception method.

The most attractive to research are CPM (continuous phase modulation) signals. Due to the constancy of their envelope, a higher rate of decrease in power spectral density is provided compared to BPSK (binary phase shift modulation). Moreover, the use of $C P M$ signals when choosing certain parameters and an effective algorithm allows achieving better noise immunity than using BPSK signals. The increase of the noise immunity in this case is explained by the fact that many different symbols differ not only in frequency, but also in the initial phase. Hence, adjacent symbols $C P M$ signals have an intersymbol phase relationship (IPR), since the initial phase of any symbol depends on several previous information symbols $[2,5,6]$.

This study focuses on CPM FR (full response) signals. In this case one symbol of the information sequence is transmitted during the symbol time. However, CPM PR (partial response) signals can be used to conserve frequency resources and improve power performance. In this case, the information transfer rate remains the same and the symbol time is increased by a factor $L$, where $L$ is an ineteger $[1,7,10]$.

This article is devoted to the estimation of the noise immunity of binary $C P M$ signals and to the study of the influence of the parameters of these signals on the noise immunity at fixed values of $E_{b} / N_{0}$.

\section{Potential noise immunity analysis of the $C P M$ signals}

In general $C P M$ signal can be written:

$$
s(t)=\sqrt{\frac{2 E}{T_{S}}} \cos \left(\omega t+\varphi\left(t: I_{n}\right)\right) \quad 0 \leq t \leq N T,
$$

where $E$ is a bit energy;

$\varphi\left(t: I_{n}\right)$ - function is used to describe the phase trajectory over a given time interval $[7,9,10,12]$ :

$\left(t: I_{n}\right)=\theta_{n}+2 \pi h q(t-n T) \quad 0 \leq t \leq N T$,

$I_{n}$ - data symbols, each taking one of the values \pm 1 ;

$\theta_{n}$ determines the depth of IPR depending on the modulation index $h$ used in the DCS:

$\theta_{n}=\pi h \sum_{\mathrm{K}=-\infty}^{n-1} I_{k}$ $h$ - modulation index. This parameter determines the spectral properties and energy efficiency of CPM signals.

In modern DCS MSK (minimum shift keying) is widely used. It is a $C P M$ signal with modulation index 0.5 .

$q(t)$ - phase pulse $(P P)[2,5,6]$. It defines the law of phase change and the level of out-of-band emissions:

$$
q(t)=\int_{0}^{t} g(t) d t \quad 0 \leq t \leq T,
$$

Formulas (5) determine the $P P$ for a rectangular baseband pulse $(1 R E C)$ and a pulse with non-linear phase law of the «raised cosine» class $(1 R C)$. This class is used to reduce the level of out-of-band emissions:

$$
\begin{aligned}
& q_{1 R E C}(t)=\left\{\begin{array}{c}
0,(t<0), \\
\frac{t}{2 T},(0 \leq t<T) \\
\frac{1}{2},(t \geq T)
\end{array}\right\} \\
& 0,(t<0), \\
& q_{1 R C}(t)=\left\{\begin{array}{c}
1 \\
\frac{1}{4}\left(1-\cos \frac{\pi t}{T}\right),(0 \leq t<T) \\
\frac{1}{2},(t \geq T)
\end{array}\right\}
\end{aligned}
$$

In according to the geometric interpretation of signal theory the potential noise immunity is determined by the minimum $d^{2}{ }_{\min }$ between the ends of two signal vectors (two phase trajectories). For the binary case $d^{2}$ min is defined:

$$
d_{\text {min }}^{2}=\lim _{N \rightarrow \infty} \min _{i, j} \frac{1}{T} \int_{0}^{N T} 1-\cos \left(\varphi\left(\left(t: I_{i}\right)-\varphi\left(t: I_{j}\right)\right)\right) d t,
$$

where $N$ - the number of symbol intervals involved in deciding on the value of the first symbol of the transmitted information sequence. The values obtained by the formula (6) are normalized to the $2 E$ value $[2,6,7]$

Of particular interest is the upper bound $d^{2}{ }_{\mathrm{B}}$ of the Euclidean distances. The upper bound determines the maximum for a given modulation index energy difference between the two signals before the first merging $\left(d^{2}{ }_{\text {min }}=0\right)$ of the phase trajectories $[2,6,7]$. It is used to determine the potential noise immunity of CPM signals and is a critical value. The upper bound value for $1 R E C$ for corresponding $h$ is defined by (7):

$$
d_{\mathrm{B}}^{2}(h)=2\left(1-\frac{\sin (2 \pi h)}{2 \pi h}\right),
$$

When calculating the minimum $d^{2}{ }_{\min }$, all values exceeding the upper bound $d_{\text {B }}^{2}$ are not taken into account in the future. The algorithm for calculating the dependence of the minimum Euclidean distances on the modulation index is considered in detail in $[2,4]$.

Figure 1 is a good illustration of $d^{2}{ }_{\min }$ versus $h$ for a given $N$ (bit decision intervals) and phase pulse $1 R E C, 1 R C$.
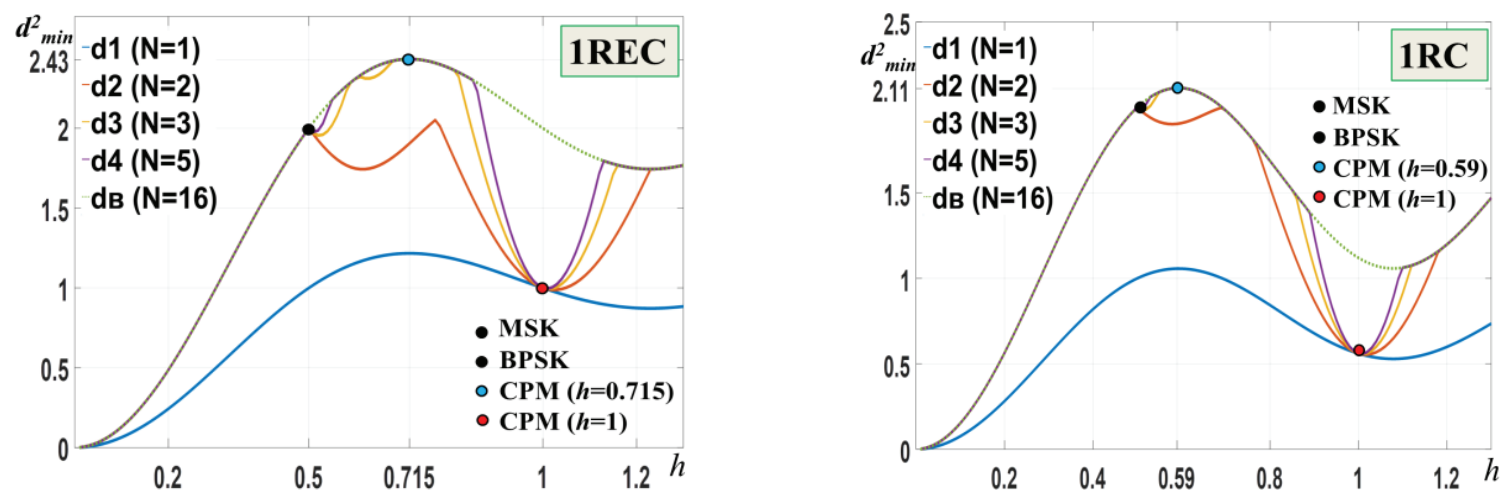

Fig. 1. Euclidean distances versus modulation index for binary $C P M F R$ 
Analysis of $d^{2}{ }_{\text {min }}$ allows selecting the values of $h$, the use of which makes it possible to increase the noise immunity of $C P M$ signals compared to BPSK and MSK. It also makes it possible to emphasize the values of the modulation indices $h$, the use of which is impractical. However, BEP estimates are needed to decide whether a specific modulation index in DCS is appropriate. $B E P$ estimates determine the DCS immunity at fixed values of $E_{b} / N_{0}$.

Experimental estimation of $C P M$ signals noise immunity. Study of the influence of modulation index and phase pulse shape on the $B E P$ value.

Determination of the dependence of $B E P$ on $E_{b} / N_{0}$ for $C P M$ signals is closely connected with finding the dimension of the signal space, determining the spatial packing of signals vectors in it. Then it's necessary to divide the signal space into solution regions and to enumerate all variants of errors. It's extremely difficult to obtain an analytical solution to this problem. For this reason, the decision was made to abandon the exact calculation of the BEP. This difficulty is overcome in practice by calculating the upper limit of this probability.

In $[2,6]$ it is proposed to estimate the probability of error using the combined upper limit:

$$
B E P \leq \frac{1}{m^{N-1}} \sum_{k}^{N} \sum_{l}^{N} 1-\Phi\left[\frac{D\left(P_{\alpha, N}^{1} ; P_{\beta, N}^{2}\right)}{\sqrt{2 N_{0}}}\right],
$$

$D\left(P_{\alpha, N}^{1} ; P_{\beta, N}^{2}\right)$ - Euclidean distance between information sequences $P^{1}$ and $P^{2}$ of length $N$ with a different first symbol;

$\Phi(x)$ - tabulated Crump function:

$$
\Phi(x)=\frac{1}{\sqrt{2 \pi}} \int_{-\infty}^{x} e^{\frac{z^{2}}{2}} d z=\frac{1}{2}+\frac{1}{2} \operatorname{er} f\left(\frac{x}{\sqrt{2}}\right),
$$

However, the combined upper limit turns out to be too overestimated and can undeservedly exclude $C P M$ signals with a sufficiency high but difficult to calculate noise immunity out of consideration. Thus, the simplified method for evaluating the noise immunity isn't suitable for analyzing the noise immunity of CPM signals.

Therefore, a more accurate determination of the dependence of $B E P$ on $E_{b} / N_{0}$ for $C P M$ signals is possible through simulation only. For this, the authors developed a simulation model of a radio channel with $C P M$ using the Matlab $2016 b$ trial package [3]. Decoding of the received sequences is carried out according to the Viterbi algorithm, which allows taking into account the $I P R$.

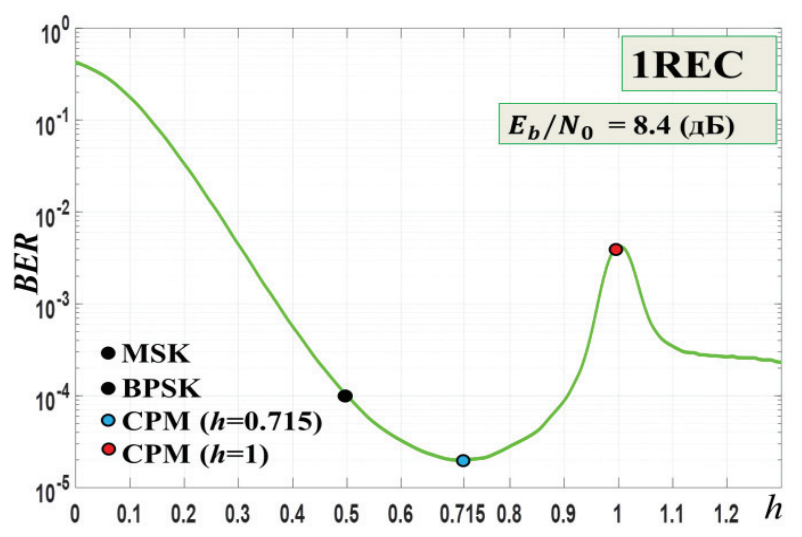

The number of symbols of the transmitted sequence is chosen based on the authenticity requirements (confidence level) of obtaining estimates of the noise immunity of $D C S$ with $C P M$. According to the theory of mathematical statistics, the value $V$ of the number of transmitted symbols is a function of the error probability per bit and confidence level.

$B E R$ (bit error rate) is taken as an estimate of the BEP. BER is the rate $m / V$ of the occurrence of an event consisting in the erroneous reception of $m$ symbols from the total number of $V$ received symbols $[8,11]$.

The following to the random reasons, the $B E R$ estimate may generally differ from $B E P$. Values are introduced: $\varepsilon-$ the accuracy of the estimate и $\alpha$ - the authenticity of estimate:

$|B E P-B E R|<\varepsilon$ и $\alpha=P\{B E P-B E R \mid<\varepsilon\}$

In this case, the number $V$ of transmitted symbols required to obtain an estimate with accuracy $\varepsilon$ and authenticity $\alpha$ is given by:

$$
V=t_{\alpha}^{2} \frac{B E R(1-B E R)}{\varepsilon^{2}}
$$

$t_{\alpha}$ Student's coefficient. With a confidence level of 0.95 and a sufficiently large value of the transmitted symbols $V$ the Student's coefficient will be 0.95 .

Table 1 shows the data that make it possible to determine the minimum number of symbols $V$ f or various values of the $B E P$.

Table 1

The number $V$ of symbols needed to estimate the $B E P$

\begin{tabular}{|l|l|l|l|l|}
\hline$P_{b}$ & $\varepsilon=0.05^{*} P_{b}$ & $\varepsilon=0.1 * P_{b}$ & $\varepsilon=0.15^{*} P_{b}$ & $\varepsilon=0.2 * P_{b}$ \\
\hline $10^{-1}$ & $1.38^{*} 10^{4}$ & $3.46^{*} 10^{3}$ & $1.54 * 10^{3}$ & $8.65 * 10^{2}$ \\
\hline $10^{-2}$ & $1.52 * 10^{5}$ & $3.8^{*} 10^{4}$ & $1.69 * 10^{4}$ & $9.51 * 10^{3}$ \\
\hline $10^{-3}$ & $1.54 * 10^{6}$ & $3.84 * 10^{5}$ & $1.71 * 10^{5}$ & $9.59 * 10^{4}$ \\
\hline $10^{-4}$ & $1.54 * 10^{7}$ & $3.84 * 10^{6}$ & $1.71 * 10^{6}$ & $9.6^{*} 10^{5}$ \\
\hline $10^{-5}$ & $1.54 * 10^{8}$ & $3.84 * 10^{7}$ & $1.71 * 10^{7}$ & $9.6^{*} 10^{6}$ \\
\hline
\end{tabular}

The estimates of the BEP $(B E R)$ obtained in the course of simulation modeling for $C P M F R$ signals with different modulation indices $h$ at $E_{b} / N_{0}=8.4 \mathrm{~dB}$ are shown at figure 2 .

The reliability of the results is ensured by the coincidence of the values of $E_{b} / N_{0}$ of the known radio signals obtained during the simulation with their a priori known values. So, for BPSK and $M S K$ signals having the same $B E P$ value at a fixed value of $E_{b} / N_{0}$, to ensure $B E P=10^{-4}$ the value $E_{b} / N_{0}=8.4[7,10]$.

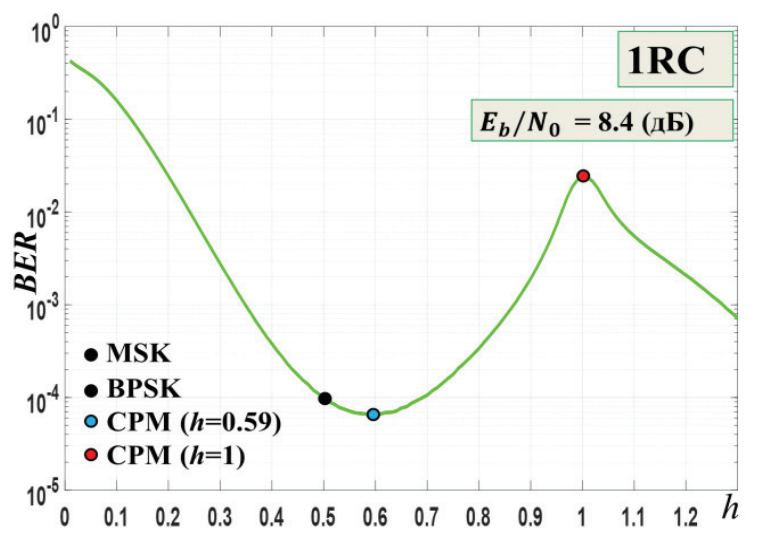

Fig. 2. Dependence of the $B E R$ of $C P M F R$ signals on the modulation index $h$ at a fixed value of $E_{b} / N_{0}=8.4 \mathrm{~dB}$ 
The adequacy of the results obtained is confirmed by the fact that results of simulation and theoretical data correspond to each other. For a $1 R E C$ phase pulse, the maximum $d^{2}{ }_{\text {min }}$, and, consequently, the maximum noise immunity is achieved for the modulation index $h=0.715$ at $N=3$ and reaches the value $d^{2}{ }_{\min }=2.43$. This result is the same as those obtained in the studies $[2,5]$. Figure 2 shows that for $h=0.715$ there is a minimum value of the $B E R$. In the range of $h$ values from 0.5 to 0.715 an increase in the values of Euclidean distance is observed (see Figure 1). Figure 2 illustrates that for the specified range of values of $h$ there is a decrease in the values of the $B E R$. A further increase of $h$ leads to a decrease in the values $d^{2}{ }_{\min }$, and an increase in the $B E R$ to the value of modulation index $h=1$. For this $h$ the maximum value of the $B E R$ is observed in the range of modulation indices from 0.5 to 1 . This fact is explained by the fact that when $h=1$ there is no $I P R$ in the $C P M$ signals $[2,6,7]$.

Similarly, for the $1 R C$ phase pulse in the modulation index range from 0.5 to 0.6 , it can be seen that the corresponding Euclidean distances $d^{2}{ }_{\mathrm{B}}$ increase, but starting from 0.6 and up to 1 , a rather sharp decrease in the values of the Euclidean distances is observed. In the specified range, there are significant differences between the $1 R C$ from the $1 R E C$, which demonstrates an increase in $d^{2}{ }_{6}$ up to the value $h=0.715$. Further fall of $d^{2}{ }_{\mathrm{B}}$ to $h=1$ is clearly less pronounced than $1 R C$ phase pulse. When comparing the above dependence, it can be seen that both CPM FR signals have the same minimum Euclidean distances at the modulation index $h=0.5(M S K)$. With an increase in the value of $h$, the largest Euclidean distance has a signal with $1 R E C$ phase pulse.

Table 2 shows the values of the upper bound of the Euclidean distances $d_{\mathrm{B}}^{2}$ for CPM FR signals of which use is of practical interest, the values of $E_{b} / N_{0}$ at which the $B E P=10^{-4}$ is provided, and error reduction factor $k$ in comparison with the used BPSK, MSK.

Table2

Comparing CPM FR to BPSK, MSK signals

\begin{tabular}{|c|c|c|c|c|}
\hline $\begin{array}{c}\text { Modulation } \\
\text { index, } h\end{array}$ & $\begin{array}{c}\text { Phase } \\
\text { pulse, } q(t)\end{array}$ & $\begin{array}{c}\text { The upper } \\
\text { bound, } d^{2}{ }_{\mathrm{B}}\end{array}$ & $\begin{array}{c}E_{b} / N_{0}, \\
(\mathrm{~dB})\end{array}$ & $\begin{array}{c}\text { Error reduction } \\
\text { factor, } k\end{array}$ \\
\hline 0.66 & 1REC & 2.40 & 7.56 & 4.11 \\
\hline 0.715 & 1REC & 2.43 & 7.51 & 4.85 \\
\hline 0.55 & $1 \mathrm{RC}$ & 2.09 & 8.09 & 1.25 \\
\hline 0.59 & $1 \mathrm{RC}$ & 2.11 & 8.05 & 1.55 \\
\hline
\end{tabular}

As can be seen from table 2 the use of CPM FR signals with the indicated modulation indices $h$ can significantly increase the noise immunity of DCS in comparison with the used BPSK and MSK signals.

\section{Estimation of the noise immunity $C P M$ FR signals}

It is proposed to pre-select signals for DCS using the $d^{2}{ }_{\min }$ between signals, the final selection of signals using the $B E P$.

Estimation includes 5 points:

1. De nition of input data: choice of the value of $E_{b} / N_{0}$ for which is necessary to obtain an estimate of the noise immunity, selection of phase pulse shape, bit rate, selection modulation index $h$ range, the values of confidence level and authenticity during simulation.

2. D ermination of the potential noise immunity of $C P M F R$ signals by calculating the Euclidean distances according to (6) within the specified range of the modulation index $h$.

3. hoice of the values of the modulation indices $h$ with greater Euclidean distances than those of the used BPSK and MSK signals.
4. mulation modeling for given input data and modulation index values defined in item 3 .

5. nalysis of the results obtained. Checking the correspondence of theoretical data to the research results. Taking into account the complexity of the hardware and software implementation of signal shaping devices, the issue of the expediency of using one or another modulation index $h$ of the phase pulse shape in the designed $D C S$ is being resolved.

\section{Conclusion}

For a preliminary estimation of the noise immunuty of $C P M$ $F R$ signals using the geometric interpretation of the signal theory, an analysis of the potential noise immunity was carried out. Analytical dependences on the modulation indices $h$ are obtained for 2 types of radio signals of the studied class. Analytically the presence of a number of indices by modulation has been established, the use of which in the designed $D C S$ makes it possible to achieve more nise immunity than when using the known BPSK and MSK signals.

An estimate of $B E P$ for a given class of signals was obtained using a simulation model. It was found that the results of simulation and theoretical data are consistent with each other. Estimates of the BEP are obtained for a CPM FR signal with different modulation indices $h$ at a fixed value $E_{b} / N_{0}=8.4 \mathrm{~dB}$. Better noise immunity in comparison with non-linear laws of phase change $1 R C$ has $1 R E C$ phase pulse.

Thus, the results of the study make it possible to emphasize the modulation indices $h$ for $C P M F R$ signals, having more noise immunity then the known $B P S K$ and $M S K$ signals. In addition, the results become possible to estimate the $B E P$ for $C P M F R$ signals at fixed values of $E_{b} / N_{0}$ and a selected phase pulse shape with a given accuracy.

\section{References}

1. Aulin T., Sundberg W. Continuous phase modulation - Part II: Partial response signaling. IEEE. 1981. Vol. com - 29, 3. P. 210-225.

2. Aulin T., Sundberg, W. Continuous phase modulation - Part I: Full response signaling. IEEE. 1981. Vol. com - 29. №3. P. 196-209.

3. Azarov A.I. Continuous phase modulation radio channel. Certificate of state registration of computer programs №2019617763.

4. Azarov A.I., Anoshkin A.V. Potential noise immunity CPM signals. News of the Tula Institute No. 7, 2018. P. 420-427.

5. Detwiler T. Continuous phase modulation for high speed fiber-optic links. A thesis presented to the academy faculty. Georgia Institute of Technology. 2011. $177 \mathrm{p}$.

6. Emelyanov P.B., Paramonov A.A. Discrete CPM signals Foreign radio engineering. No. 12, 1990. P. 17-34.

7. Proakis Jh. Digital communications, 5-th edition: Moscow: Radio and Communication, 2000. $801 \mathrm{p}$.

8. Prohorov Y.V., Rozanov Y.A. Probability theory. Moscow: Science, 1973. 494 p.

9. Semenov V.Y. Demodulation method for continuous phase modulation signals based on least-squares method. Radioelectronics and Communication Systems. No.4, 2018. P. 153-156.

10. Sklar B. Digital communications. Fundamentals and applications, 2-th edicition Moscow: Williams, 2016. 1104 p.

11. Ventcel E.S. Probability theory, 6-th edition. Moscow: High Shcool, 1999. 576 p.

12. You Zhou, Rongke Liu, Ruifeng Duan, Bofeng Jiang. A lowcomplexity noncoherent Maximum Likelihood Sequence Detection scheme for continuous phase modulation in aeronauticl telemetry. International Journal of Aerospace Engineering, 2015. P. 1-16. 


\title{
ELECTRONICS. RADIO ENGINEERING
}

\section{ОЦЕНКА ПОМЕХОУСТОЙЧИВОСТИ ЧАСТОТНО-МОДУЛИРОВАННЫХ СИГНАЛОВ \\ С НЕПРЕРЫВНОЙ ФАЗОЙ И ПОЛНЫМ ОТКЛИКОМ \\ НА ОСНОВЕ ИМИТАЦИОННОГО МОДЕЛИРОВАНИЯ}

\begin{abstract}
Азаров Андрей Игоревич, Военная академия РВСН имени Петра Великого, г. Балашиха, Россия, azarofffI985@yandex.ru
Бударин Евгений Валерьевич, НИИ Калининградского филиала Института земного магнетизма, ионосферы

и распространения радиоволн имени Н.В. Пушкова, г. Калининград, Россия, zhenyoker23I@yandex.ru
\end{abstract}

\section{Аннотация}

Статья посвящена исследованию помехоустойчивости частотно-модулированных сигналов с непрерывной фазой и полным откликом. Предварительная оценка помехоустойчивости проведена путем расчета минимальных евклидовых расстояний между сигналами. Оценки помехоустойчивости исследуемых сигналов получены экспериментально. Представлены результаты имитационного моделирования при фиксированном значении отношения энергии бита к спектральной плотности мощности шума для исследуемых сигналов с заданными индексами модуляции и формой фазового импульса. Результаты исследования позволяют выделить сигналы, обладающие помехоустойчивостью лучшей, чем используемые в настоящее время сигналы с BPSK и MSK, а также получить для них оценки вероятности ошибки на бит с заданной точностью. Повышение помехоустойчивости становится возможным за счет межсимвольной фазовой связи, возникающей вследствие отсутствия разрывов фазы несущего колебания на границах символьных интервалов, и ее учета при декодировании принимаемой последовательности с использованием алгоритма Витерби.

Ключевые слова: помехостойчивость, частотно-модулированные сигналы с непрерывной фазой и полным откликом, евклидово расстояние, индекс модуляции, вероятность ошибки на бит.

\section{Литература}

I. Aulin T., Sundberg W. Continuous phase modulation - Part II: Partial response signaling. IEEE. I98I, vol. com - 29, №3, p.210-225.

2. Aulin T., Sundberg W. Continuous phase modulation - Part I: Full response signaling. IEEE. I98I , vol. com - 29, №3, p.196-209.

3. Азаров А.И. Программа имитационного моделирования радиоканала с непрерывной частотной модуляцией. Свидетельство о государственной регистрации программ для ЭВМ №2019617763 / Дата государственной регистрации в Реестре программ 20 июня 2019 г.

4. Азаров А.И., Аношкин А.В. Потенциальная помехоустойчивость частотно-модулированных сигналов с непрерывной фазой // Известия ТулГУ. № 7, 2018. С. 420-427.

5. Detwiler T. Continuous phase modulation for high speed fiber-optic links. - A thesis presented to the academy faculty. Georgia Institute of Technology. 20II. 177 p.

6. Емельянов П.Б., Парамонов А.А. Дискретные сигналы с непрерывной фазой. М.: Зарубежная радиотехника. № 12. 1990. С. 17-34.

7. Прокис Дж. Цифровая связь: монография. М.: Радио и связь, 2000. $80 \mathrm{I}$ с.

8. Прохоров Ю.В., Розанов Ю.А. Теория вероятностей. М.: Наука, 1973. 494 с.

9. Semenov V.Y. Demodulation method for continuous phase modulation signals based on least-squares method // Radioelectronics and Communication Systems. No. 4. 2018. P. 153-156.

10. Скляр Бер. Цифровая связь. Теоретические основы и практическое применение, 2-е изд. М.: И. Д. Вильямс, 2016.1104 с.

II. Вентиель Е.С. Теория вероятностей: учеб. для вузов. 6-е изд. М.: Высш. шк., 1999. 576 с.

12. You Zhou, Rongke Liu, Ruifeng Duan, Bofeng Jiang. A low-complexity noncoherent Maximum Likelihood Sequence Detection scheme for continuous phase modulation in aeronauticl telemetry // International Journal of Aerospace Engineering. №I. 20I5. P. I-I6.

Информация об авторах:

Азаров Андрей Игоревич, научный сотрудник, к.т.н., Военная академия РВСН имени Петра Великого, г. Балашиха, Россия

Бударин Евгений Валерьевич, инженер, НИИ Калининградского филиала Института земного магнетизма, ионосферы и распространения радиоволн имени Н.В. Пушкова, г. Калининград, Россия 